\title{
Losing self to discover national citizenship: contestations over parental rights among the post-Soviet foreign wives in China
}

DOI:

10.1080/14650045.2019.1620208

\section{Document Version}

Accepted author manuscript

Link to publication record in Manchester Research Explorer

Citation for published version (APA):

Barabantseva, E. (2019). Losing self to discover national citizenship: contestations over parental rights among the post-Soviet foreign wives in China. Geopolitics. https://doi.org/10.1080/14650045.2019.1620208

\section{Published in:}

Geopolitics

\section{Citing this paper}

Please note that where the full-text provided on Manchester Research Explorer is the Author Accepted Manuscript or Proof version this may differ from the final Published version. If citing, it is advised that you check and use the publisher's definitive version.

\section{General rights}

Copyright and moral rights for the publications made accessible in the Research Explorer are retained by the authors and/or other copyright owners and it is a condition of accessing publications that users recognise and abide by the legal requirements associated with these rights.

\section{Takedown policy}

If you believe that this document breaches copyright please refer to the University of Manchester's Takedown Procedures [http://man.ac.uk/04Y6Bo] or contact uml.scholarlycommunications@manchester.ac.uk providing relevant details, so we can investigate your claim.

\section{OPEN ACCESS}




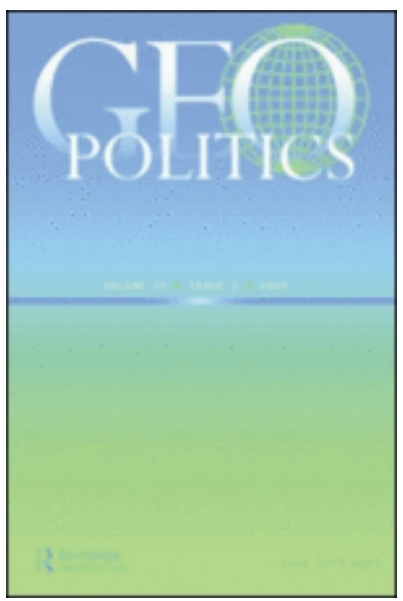

\section{Losing self to discover national citizenship: contestations over parental rights among the post-Soviet foreign wives in China}

\begin{tabular}{|r|l|}
\hline Journal: & Geopolitics \\
\hline Manuscript ID & FGEO-2018-0086.R2 \\
\hline Manuscript Type: & Manuscript Submission \\
\hline Keywords: & Asia, Identity, citizenship, marriage, migration \\
\hline \multicolumn{2}{|l}{} \\
\end{tabular}

\section{SCHOLARONE ${ }^{\text {M }}$ \\ Manuscripts}




\title{
Losing self to discover national citizenship: contestations over parental rights among the post-Soviet foreign wives in China
}

Elena Barabantseva*

\begin{abstract}
Drawing on the life stories of post-Soviet women from Ukraine and Russia who married Chinese citizens and moved their married lives to China, this article examines how these women engage in intimate geopolitics in the adverse immigration environment for foreign family members. The elaborated argument maintains that the women -- driven by the uncertainty surrounding their legal and socio-economic status and the fear of forced separation from their children -- resort to their home citizenship or informal dual citizenship arrangements as leverage to defend parental rights against the backdrop of China's strict single citizenship regime. The women develop strategies to ensure their parental rights through citizenship structures available to them, and seek to remedy their emotional uncertainties amid the environment of limited and tenuous immigrant and family statuses in China. This paper develops analytical potential of intimate geopolitics through an analysis of post-Soviet wives' subjectivities constituted through the interplay of geopolitical structures and their emotional intensities.
\end{abstract}

Key words: China, child's citizenship, intimate geopolitics, marriage migration, maternal rights, post-Soviet identities.

\section{Acknowledgements}

Funding for this research was provided by the UK Economic and Social Research Council (Ref ES/L015609/1) as part of the international China-Europe collaborative project 'Immigration and the Transformation of the Chinese Society' (2015-2019). I am grateful to the two anonymous readers of Geopolitics, the 'Intimate Geopolitics' project fellow researchers, Aoileann Ní Mhurchú and V. Spike Peterson in particular, and William A. Callahan, Elaine Ho, and Michaela Pelican for their careful comments on the earlier drafts of this article that helped to improve my argument. All inconsistencies in the analysis remain mine.

Elena Barabantseva (e.v.barabantseva@manchester.ac.uk) is Senior Lecturer in Chinese International Relations in Politics Department and an affiliate member of Manchester China Institute at the University of Manchester. 


\section{Introduction}

Marriage migration as a global phenomenon and as the most popular form of migration in East Asia is a crossroads where negotiations of gender, personal desires, and governance of population through labour markets, marriage, property and citizenship law take place (Constable 2003, Robinson 2007, Jones and Shen 2008, Jones 2012, Faier 2015). These migration trends have been researched from the point of view of the changing demographic and fertility landscapes in the receiving societies, regional and global commodified marriage market (Chang and Wang 2002) and shifting labour relations (Piper and Roces 2003). Although the restrictive nature of citizenship laws for migrant women has also come under academic scrutiny, much less research has been conducted on migrant women's strategies of survival, adaptation, and reaffirmation of their independent subjectivities. These strategies are manifested, among other areas, in how they negotiate parental rights vis-a-vis their citizen spouse. In this essay I discuss how, amidst uncertainty, fear of separation from their children and mistrust of the Chinese state's recognition and protection of their parental rights, post-Soviet migrant spouses employ inconsistencies in citizenship regimes to their advantage in the effort to secure their parental rights. In the process, I argue, they engage in intimate geopolitics through the use of a geopolitical means of national citizenship as an intimate defense mechanism of their parental rights. Intimate geopolitics here helps to highlight emotionally rich and creative sets of practices informing strategies of survival and resourceful ways of living in the environment of competing citizenship regimes. This article offers a new perspective on women's narrated experiences of marriage migration and their negotiations of maternal rights. It shows that the intense fears of separation from their children prompt women to proactively use their national citizenship to secure their parental rights.

Marriage migration to Mainland China is a relatively new but quickly developing phenomenon changing the social fabric of Chinese society (Jeffreys and Wang 2013). A late-comer to the global marriage migration market on the receiving end, China has been primarily known and researched as a source of brides for more affluent destinations in Asia and the West. In the mid 2000s, women from China constituted the highest proportion of foreign wives in Taiwan, South Korea, and Hong Kong, where they became subjects of restrictive residency, work, and citizenship 
1 'Foreign bride' (wai ji xin niang) is an established term in popular and scholarly discourses on marriage migration in China. It has strong connotations with human trafficking, illegal migration, and commodification of marriage (Shen 2012).

2 At least two TV drama series were dedicated to Russian-Chinese romantic relations in the 2000s:

'North-East Love Story' (2012), and 'My Natasha' (2012)

${ }^{3}$ Xiang Qin Tuan produced a series of forty short episodes entitled 'Love at First Sight' aired between March and June 2016 on the theme of Chinese-Foreign marriages focusing primarily on romantic relations between Chinese men and women from post-Soviet states, 8 May 2016, http://www.le.com/ptv/vplay/24801873.html.

${ }^{4}$ Shui Changong (2014) 'Why do Russian girls marry Chinese guys?' blog, 25 November, http://www.360doc.com/content/14/1125/09/12361654_427856310.shtml.

${ }^{5}$ Koshoibekova, Nargiz (2015) 'Russian newspaper encourages Russian-Chinese marriages', The World of Chinese, 2 June 2015, www.theworldofchinese.com/2015/06/russian-newspaperencourages-russian-chinese-marriages/ 
contemporary global order, and opens up space for examining formulations, practices and negotiations of the preconceived norms and laws of marriage, family structures, gender relations, nationalism and citizenship (Constable 2003, Piper 1997). This article looks to a less-studied aspect of the emotional struggles involved in marriage migration, and explores how migrant women address and resolve their perceived uncertainty regarding their parental rights (see also Turner and Vera Espinoza in this special for further discussion about the emotional struggles linked to marriage migration). This article is particularly concerned with how migrant women negotiate their unstable role as a foreign wife in a hostile legal environment, which is complicated by traditional family values and gender norms in China.

My study of Chinese-post-Soviet marriage migration reveals the complexity and nuances of geopolitics cutting across socio-economic, political, personal, emotional, and gendered forces shaping migratory journeys. The women whose stories inform the analysis in this paper "freely" chose to marry and move to China; they did so for multiple reasons, and on their journey discovered and engaged with a complex web of intimate geopolitics (Harker and Martin 2012; Morrison, Johnston and Longhurst 2012; Pain and Staeheli 2014). Their voluntary decision to migrate and marry in China escapes easy categorizations and labeling, and should be understand in the context of an array of gendered structural and personal reasons. The term 'intimate geopolitics' here captures the inextricability of socio-political and economic structures and processes from intimate decisions and responses taking place in particular spatialtemporal contexts (Harker and Martin 2012, Peterson 2014, 2017). Migration decisions borne out of existing socio-economic pressures and gender ideologies and relations -that are impossible to disentangle ${ }^{6}$-- have geopolitical implications, as they are closely entwined with citizenship laws and immigration regulations that define the conditions for national membership. The emotional efforts and costs invested in the decision first to move and then to make a family life in China successful are inseparable from citizenship and immigration laws and changing gender relations and family norms in both sending and receiving societies.

The empirical focus on Chinese-post-Soviet marriages in this article disturbs the prevalent dichotomy between the West and its Eastern Others in analyses of globally intimate 'gendered geographies of power' (Pessar and Graham 2001, Klinke

\footnotetext{
${ }^{6}$ Säävää (2010) makes a similar observation in her research with Albanian and Russian migrant women in Finland.
} 
2016). Academic enquiries into globalization of intimate encounters have noted the predominant dynamics between women from the poorer societies of the global South and men from the affluent global North (Constable 2003). A focus on Chinese-postSoviet marriages thus shifts attention from this dichotomy to interrogate how intimate geopolitics play out in the personal relations of those who normally take up the position of an Orientalized Other. The article acknowledges agency of migrant wives, and seeks to understand how post-Soviet migrant spouses negotiate and reconstruct their subjectivities in the spaces afforded to them at the interstices between citizenship, marriage, migration, and motherhood in China. The analysis draws on life stories (Atkinson 1998) recounted by thirty women who came to China from Russia and Ukraine between the mid-1990s and mid-2010s; they were at different stages of their married and post-married lives at the point of the interview, all of which took place between November 2016 and June 2017. Further interviews with staff at the Russian consulates in Beijing and Shenyang complement interpretations of personal narratives with the sending state's perspective.

My central argument is that post-Soviet migrant women in China are driven by their intense fear of separation from their children to use the conflicting character of citizenship laws to ensure their maternal rights. I develop the argument in four sections. In the first section, I discuss how the women look back on their migratory journeys and rationalize their decisions to move for marriage to China. The upheavals of the post-socialist transitions and their impact on the system of values and social priorities feature prominently in the narratives of escape and pursuit of better life opportunities. Post-socialist uncertainties, familial pressures and their desire for a better life contribute to their decision to move to China yet cannot be separated from the intimate forces of physical and emotional attraction that these women developed towards their husbands before embarking on the journey to China. The process of reinventing themselves in a new socio-cultural environment prompts re-evaluation of their life-worlds and norms of married life. For many, this process leads to what women call 'losing self', which is discussed in section two. The third section unpacks internal and external borders of the PRC's citizenship regime by detailing how patriarchal structures in the new immigration law exclude migrant spouses from Chinese citizenship yet embrace their children into the national collectivity. The realization that their children born in China automatically assume Chinese nationality produces among many women an acute sense of vulnerability and the fear of forced 
separation from their children. Section four explores how women redefine and exercise their agency as a foreign wife despite an uncertain future for foreign spouses' legal status in China; this is accomplished by arranging for the children to inherit her home national citizenship for the child and/or informally arranging two passports. The fragmented character and inconsistent implementation of immigration laws and administrative regulations create spaces for the women's productive interruptions of national boundaries and reinterpretations of conflicting citizenship regimes.

\section{Entering Chinese marriage}

We show that we are needless, that we marry for love, not for money. Chinese probably rejoice that they 'snapped' [us] free of charge (from conversation with Olya and Katya, 5 June 2017, Beijing).

The two main routes, often closely related, for increased personal contacts between China and the post-Soviet states since the 1990s have been mobility of Chinese people for business and education (Nyíri 2003) and, from the post-Soviet perspective, a growing interest in China, its language and culture across institutions of higher education leading to increased international study and student exchange opportunities in China. Most women who took part in this research met their future husbands in their hometowns or in China where they were on the Chinese language courses or educational exchanges themselves. In all cases discussed here, the decision to marry and settle in China was prompted by a period of romantic relationship, and sometimes pregnancy. The decision to settle in China, rather than in the woman's home country, was, in part, informed by the couple's or man's negative experiences of racist public attitudes that led to the conclusion that the life for them and their children would be easier in China. In looking back on their journeys to a family life in China, the women rationalized their decision through an interplay of economic, personal and social dimensions framed by the post-socialist transitions, and not having a better choice at the decisive moment. Although all the marriages in this study were 'free-choice', resulting from a period of romantic engagement, it was common for the women to 
express that they felt objectified by the Chinese marriage culture, were not fully accepted by their Chinese family and struggled to adapt to their foreign migrant wife status in China.

The lack of fulfilling and promising job prospects, economic stagnation, isolated environment and depreciation of university qualifications in their home countries of Russia and Ukraine were among the most commonly mentioned motivating factors. None of the research participants mentioned that their decision to marry a Chinese man was prompted by their inability to find a husband in their home country. Rather, the main reason was physical attraction in combination with the values which the men represented in the women's eyes during courtship. Lena (38) went to Beijing in the early 2000s from Vladivostok to learn the Chinese language, hoping that it would expand her employment opportunities back in Russia. She stayed in Beijing after falling in love, having a child, marrying and subsequently divorcing her husband. Looking back at her marriage trajectory she recalled the feeling of isolation and stagnation in Vladivostok, and the opportunities that Beijing life promised. The visceral experiences of post-socialist upheaval (Humphrey 2002, Oushakine 2009), with no obvious routes out of the traumatic repetitions of post-socialist crises, were closely intertwined with Lena's and other women's decisions to seek an escape which the idea of marriage in China promised. For women from the Far Eastern and Siberian parts of Russia, the sense of never-ending sequels of post-Soviet economic disasters was exacerbated by the feeling of being disconnected from the European part of Russia. Many observed that going home in the Far East for them was closer, cheaper, and faster from China than from Moscow. Women from Ukraine also talked about the appeal of better future prospects as a precursor to their decision to marry and move with their Chinese husband to China. Alyona, a 38-year-old Ukrainian woman, had a successful career as a film artist in Kiev where she met her future husband on a film set. She then followed him to China. She observed that staying in Ukraine meant for her missing out on the opportunities afforded by the fast-developing economy and creative spaces in China. This was one among a host of reasons cited - a complex web of economic, socio-political, cultural, and personal factors that motivated the women to marry in China. Even in those cases where women started subsequently to financially support their natal families back home, it would be overly simplistic to attribute their migration to economic factors alone. 
Despite freely choosing to move for married life in China, the feeling of having been (mis)led into the married life in China was commonly expressed: 'Chinese bribe us into marriage' was a sentence I recurrently heard in my conversations with Russianspeaking wives in China. 'They are emotionally bribing us with their promises of a good life, constant presents, and attention,' concluded Olya and Katya, two women married and living on the outskirts of Beijing at the time of our conversation in a Starbucks café in the Chaoyang district of Beijing; a place where they meet every fortnight to interrupt their domestic routine (5 June 2017, Beijing). The women reported being seduced by the attention and care in which their future husbands enveloped them during the courting phase, treatment which they had never observed, expected or experienced from men in their home country of Ukraine.

Marriage remains the main societal norm and route to self-realization for a woman in the post-Soviet states, as it is in post-Mao China (Fang 2013). Women critically reflect on these aspects of their up-bringing and social environment: 'They don't value women in our countries. We are all brought up by mothers who say "thank you very much for taking my poorly brought-up, uneducated daughter to marry you. Thank you for marrying her, thank you that you will look after her"' (Olya, Beijing, June 2017). The social and cultural value of marriage as the life-goal for a woman is further amplified by the familial and social pressures to marry 'on time'. Having moved away from the economic, social, and familial pressures at home, the women encounter the commodifying effects of the Chinese marriage culture.

A particular trait of the reform-era Chinese society that sets it apart from postSoviet marriage practices is the widespread custom of monetary exchange negotiated by the bride (or her family on her behalf) with the groom's family. The Chinese family 'corporate model' founded and run primarily as an economic unit has been long observed and critically interrogated by anthropologists of China (Yan 2003: 3-4). The economic and labour exchange logic of the Chinese family structure is particularly notable when the contemporary practices of dowry and bride price are considered. The 'bride price' continues to be an ordinary and widely-practiced norm accompanying the establishment of a new family. With the growing 'shortage' of women of marital age, women in China turned into agents with more bargaining power, on the one hand, and a valuable commodity, on the other. The moral foundations and the revival of Confucian patriarchal values in recent years, fuelled by the negative impact of family planning policies and decades of extensive control over the bodies of women (Hillier 
1988, Greenhalgh 1994, Judd 1994) further contributed to commercialisation of family relations in post-Mao China. For Chinese women and their families, it is common to receive a certain amount of money that the girl or her family receive as a result of marriage (the amount given to the bride depends on her household registration (hukou), her level of education, and family status) ${ }^{7}$. Historians, psychologists, and anthropologists have long observed the puzzling peculiarity and continuity of the Confucian patriarchal structures of dominance and inequality which survived historical and political upheavals and continue to underwrite China's political and economic orders (Bruckermann and Feuchtwang 2016: 40, Harell and Santos 2015: 33, Yan 2003: 149-150). Since the economic reforms of the late 1970s, these continuities have been altered by the changing social attitudes affected by the infiltrating rules of the market and individual striving for success (Yan 2003, 2013). The bride price custom is the result of the 'historical saturation' (Stafford 2013: 23) by Confucianism and fastchanging market influences on the moral landscape of family relations in China that, according to one of my interviewees, sounds bizarre to the 'European' ear or, in the words of another woman, is simply 'feudal' (20 August 2016, Beijing).

Several women blamed themselves for their lack of knowledge, and high adventurous spirit, expressing regret for not learning enough about Chinese traditions and mentality before embarking on the journey, and for not adapting to the Chinese way of life. 'They [Chinese] are not bad, we are doing them bad,' concluded Lena (Vladivostok, 16 August 2016). Olya and Katya concurred that 'we make a mistake that we show that we can do everything ourselves and don't need help' (5 June 2017, Beijing). In the process of negotiating their new 'Chinese wife' status, they struggle to accept and adapt to the cultural conventions of marriage in China. Some women found it uncomfortable and troubling to notice the social impact that their marriage had on the social status of their husbands among their peer groups. Alyona voiced this discomfort in her observation that 'Chinese men take pride in marrying a white woman, but, in reality, they don't need you'; to paraphrase, they flatter themselves by scoring higher symbolic capital and 'earning face' among their peer circle. She came

\footnotetext{
${ }^{7}$ See, for example, 'Forget dowries: Chinese men have to pay up to $\$ 24,000$ to get a bride', The Quartz. Obsession, 9 June 2013, https://qz.com/92267/in-a-reversal-of-the-dowry-chinese-men-pay-a-steep-pricefor-their-brides/, 'Tianjin fell off of the top three: the latest ranking of bride prices', 7 September 2017 , http://mp.weixin.qq.com/s? biz=MjM5MjIxMjY3NA==\&mid=2651502476\&idx =1\&sn=0 dac 25c4f8f60 8a4ca07793f25962047\&chksm=bd57a4218a202d37c4e2ff7033e85fca9485b8b104ce6ac0a604c2c4b7e4d486b de45cb64891\&mpshare $=1 \&$ scene $=5 \&$ srcid $=1001 \mathrm{vObstzwd} 3 \mathrm{oGmda} 2 \mathrm{AqYjw} \# \mathrm{rd}$,
} 
to a realisation that Chinese men do not chase white women in general but specific types, because 'they have a serious inferiority complex and only choose accessible and affordable white women' (Interview, Beijing, 20 August 2016). 'Accessible and affordable' here refers to the normative value attributed to the post-Soviet women who have not been emancipated by the developments in gender equality policies as the women in the West. Natasha similarly attributed her husband's instantaneous decision to marry her to her European background: 'We met two weeks before he was leaving Ukraine for China, and he decided straight away that he wanted to marry me. They don't even think about it, particularly if it is Russian. I didn't know before, but I realize now that it is their cultural peculiarity' (Beijing, 5 June 2017).

The women's accounts of entering Chinese marriage should be understood in a broader context of China's reform transformations and the shifting position of a white woman's body in the Chinese national imagination (see also Daigle's paper in this special issue which looks at the role of how the Cuban state regulates intimate relationships linked to national (re)construction efforts). In the early reform period, the white woman was conceived of as a distant object of consumption and a commodity, as a background or adornment of private sphere thrust into public displays of modern family life and domesticity. The white woman was an object of admiration, desire, longing, and the symbol of qualities which China lacked (Schein 1994: 147). As China's economic growth and global influence become more confident, marrying a white woman fulfils at least two closely-related national goals. The first one is the rectification of the skewed sex ratio designated as a national security concern negatively impacting economic, social, and cultural aspects of Chinese society (Das Gupta, Ebenstein and Sharygin 2010). The tacit official preference for white women as foreign brides for Chinese unmarried men is apparent in the announcements made with the support of the Chinese state institutions. In March 2018, for example, Global Times, the Chinese Communist Party's global mouthpiece, published an article suggesting that Russian-Chinese intermarriages are becoming part of the two countries' closer cooperation within the Belt and Road Initiative (Global Times 2018). In the heavily censured publishing environment, such formulation and content of the article could have only been published with the approval of censors. The second and goal, which is related to the first, is the national desire to become a powerful and respected world power with global influence epitomized in the PRC's national strategy to fulfill its China Dream (Callahan 2017). The pursuit of this China Dream is 
unequivocally tied to another reform-era goal: to increase the 'quality' of the Chinese population to make it fit for its global role (Greenhalgh 2010). In the context of these national strategy goals aimed at shifting China's position in the global order, from the status of a developing state to a major player of global capitalism, it is not surprising that the Chinese state favours a growing number of white foreign wives. Historically, intermarriages played an important role as the Chinese Empire's tool of alliance, or assimilation, with their neighbours (Teng 2013). In the contemporary context, a growing number of marriages with white women symbolizes that Chinese men become desirable husbands and reliable economically, socially and domestically. Favourable official and popular representations of such marriages work as an extension of the popular discourse of China's rise as a great economic and political power washing away the shameful memory of China's century of humiliation, and healing national insecurities that it engendered (Barmé 1995, Callahan 2004). Yet, the emotional struggles of the women who take up the positions of Chinese wives highlight the entrenched cultural attitudes to marriage, gender ideologies and ambiguous attitudes towards foreigners in the Chinese society.

\section{Losing self}

I lost ${ }^{8}$ myself somewhere, because in any case, it is a different culture, language, cuisine; your opportunities to realize yourself here are very limited (Katya, Beijing, 4 June 2017).

One of the biggest challenges for post-Soviet foreign spouses in China is to adapt to the cultural norms and socio-economic realities of family lives in a foreign context. Feeling fully accepted as a family member is challenging. Lena concluded that in Chinese families we are always guests' (16 August 2017, Vladivostok). In her observation, even if 'they nominally accepted you into their family, you will never be truly close to anyone there'. Lena was recalling the time when her marriage was deteriorating, and she did not have anyone close-by to confide in: 'I ran out of the house, and spent half a day in the park. I switched off the phone, and was crying there.

\footnotetext{
${ }^{8}$ The original Russian word used here was 'потеряла себя' that literally means 'lost myself'.
} 
In this situation, I just wanted someone to listen, feel sorry. I didn't have people like that in my house'.

When I probed whether she shared her problems with her family in Vladivostok, Lena said that she couldn't tell her mother so as not to upset her: 'Why to upset her? First of all, I am in a different country, married to a foreigner, she will worry for me. Secondly, I felt ashamed, because it was my choice after all. Many of us live like this without parents knowing much about our life. We don't know the local law, and even if we know it, we don't know how to use it, there is no one to protect us - our relatives are living far away. Not only we don't ask for help, we are ashamed of talking about it with our relatives' (Vladivostok, 16 August 2016). Natasha recalled the early days of her married life in China in a similar tone: 'At the beginning, I really wanted to go back to Ukraine. I didn't like China. I couldn't get used to it. Then, when my husband went to work abroad I entered a period of depression. I am here by myself; it was very hard. I had to get used to his family because I lived with them, had to get used to my life, to China, pregnancy, everything...' (Interview, Beijing, 5 June 2017). Katya found consolation and started developing coping mechanisms with the help of a psychoanalyst with whom she connected via Skype. Katya said: 'I simply started losing it. I want to work freely, but they don't understand why I need it. So it happens that you lose yourself. This is very hard, very hard. [The] psychotherapist helps me, and I noticed improvements, because at some point I just didn't want anything. You lose your own self to such an extent that you don't have any desires or interests. I can't call it depression; it is just complete indifference' (Beijing, 4 June 2017). Adapting to the realities of life as a migrant spouse is an exercise in tremendous emotional upheaval and mental adjustment which many women cannot cope with on their own. The topics of isolation, boredom, loneliness, and inter-cultural misunderstandings came up in every conversation. It is easier for women living in big cities with sizeable Russian-speaking communities, such as Beijing, Shanghai or Guangzhou, to build a familiar social circle, although in some cases turning to a professional help and/or faith became the preferred way of redefining their sense of self. A number of women living in Beijing where a Russian Orthodox Church operates on the territory of the Russian Embassy became regular churchgoers after their move to China.

The difficulties with cultural and familial adjustments are complicated by China's current immigration regime that does not grant holders of family guest visas (Q) permission to work, and locks migrant spouses into a dependent position or pushes 
them into the grey zone of illegal employment. The 2012 Exit-Entry Administration Law and 2013 Regulations on the administration of the 2012 law make it explicit that the work permit is issued to those foreigners whose 'labour should meet the needs of the socio-economic development of China' (Liu and Ahl 2018). The emerging immigration regime draws clear lines between visa categories: if you came to work, then work on a working visa; if you came on a family visa, then sit at home and look after children. Economic dependence on the husband's income is particularly difficult to accept for some highly-educated women who had been in the process of forging their own careers before they moved to China.

Alyona, who ran art workshops for Russian-speaking women and children in Beijing, shared that she was often overwhelmed by the feeling of sadness and loss, which she attributed to her dependent and tenuous status in China: 'I had occasional psychological meltdowns. From time to time there are moments when I feel like packing up and going home' (Interview, 31 May 2017, Beijing). She attributed her feeling of loss to her not having the right to work legally on a Chinese family-visitor visa. When we met Alyona's income was irregular and depended on the sale of her paintings and tutoring. Yet, she expressed a strong belief that for 'a modern woman' it was important to have her own income, not to depend on her husband, because if 'the husband provides for a woman completely, she becomes a slave. Even if he is a kind and caring man, not a tyrant, she depends on him' (Interview, Beijing, 31 May 2017). She went on to explain that most family conflicts with her husband were related to domestic finances: 'when I run out of money I naturally ask him, as he is earning quite well. And, because I spend his money, he feels that he has the right to blame me for spending more than I should have, and I react sensitively to this' (Interview, 31 May 2017, Beijing).

The women of this study also commented on feeling stifled by administrative restrictions and cultural differences preventing them from being included in China. Natasha shared that she felt 'like a bird in a cage, without any choice. My freedom is very limited by all these political things, [so] I feel as if I signed myself a prison sentence' (Beijing, 5 June 2017). Natasha's recognition of her family life being closely bound up with the political structures that limit her ways of belonging in China echoes experiences of immigrant spouses in other contexts (Friedman 2015). Unlike the majority of these post-Soviet migrants, who typically stay in China on two-year family visas, Natasha received a Chinese green card in 2016 after being married to her 
Chinese husband for five years, and recalled the lengthy troubles that she had faced securing the document. Yet, she questioned the card's worth: 'I even wrote a resume, why I would be useful in China.... I had to wait for the card for nearly two years. I had to get a certificate in Ukraine that I didn't have a criminal past. This certificate is only valid for one month. At the time, Orange revolution was unfolding in Ukraine. My father went through the barricades. He had to pay 1,000 USD in order to get this certificate, so that I don't appear in person. So, it cost me a lot of money and nerves to get this card. But I don't even know if it is of any use... For example, if I divorce my husband, what do I do with this card? Will they take it away from me? I don't even know about it' (Interview, Beijing, 5 June 2017).

On the journey to married life in their adoptive country, women discover the commodifying features of marriage in China, gaps in cultural and familial norms, and imposed visa restrictions. When the birth of a child enters the horizon of family life, the acute awareness of the lack of recognition of the foreign mother's parental rights prompt some women to reinvent their subjectivity beginning with the acknowledgement of their vulnerable position as a foreign spouse in China.

\section{Acknowledging vulnerability}

We ourselves get to such point in our family lives, humiliated, with a real possibility of not being able to see our children again (Lena, Vladivostok, 16 August 2016,)

According to the PRC's Nationality Law (1981), a child born to at least one Chinese citizen parent on the territory of PRC automatically becomes a Chinese citizen. Furthermore, the Chinese state exercises a strict single citizenship regime precluding the children from becoming dual citizens. Since there is no clear route for an immigrant spouse to naturalise in China ${ }^{9}$, the ambiguity and incompatibility of her and her children's statuses in China are a source of considerable anxiety for the women

\footnotetext{
${ }^{9}$ Although Chinese Nationality Law includes provisions for naturalization of close relatives of Chinese citizens, the conditions for meeting the required criteria are very high and difficult to meet. Liu Guofu, China's influential immigration lawyer, has proposed to lower the required criteria for naturalization of 'foreign brides' in China (Liu 2019).
} 
once they become aware of possible problems through word of mouth, their own experience, or coincidental events. ${ }^{10}$

Chinese citizenship has external and internal borders constituted in parallel and in relation to each other. On the outside, the Nationality Law clearly defines who the Chinese citizen is and outlines a single citizenship regime; internally, the household registration system (hukou) complements this citizenship architecture by placing citizens into the categories of rural and urban populations, distributing education and healthcare provision, social rights, and assigning normative positions in accordance with their place of registration and the ethnic category they are assigned to (Jakimow and Barabantseva 2016). A birth certificate is issued at the hospital where the birth takes place, yet the child's citizenship status is not complete until $\mathrm{s} / \mathrm{he}$ is written into the hukou system, at which point the child becomes a full Chinese citizen.

Sasha has lived in Changchun since 1996 when she moved there from Moscow with her Chinese husband and their two daughters. She met her husband while working in a Chinese restaurant in the suburbs of Moscow. Sasha gave birth to their third girl in Changchun, where she lived with her three daughters at the time of our first meeting in 2016. Her husband had been working in Guangzhou for several years now and came to visit them once a year during the Chinese New Year. The only reason she had not sought divorce, she told me, was because of her fear that the husband would not let her keep their younger daughter: 'He would give her to his sister, or the wife of his older brother. He will not look after her. Why would I want it?' (Sasha, Changchun, 8 August 2016). The older two daughters were already of age and worked independently, although they continued to live with their mother. Sasha was shocked to find out that her daughters were Chinese citizens, a fact she discovered when the Chinese authorities refused to put Chinese visas in their Russian passports. Their Russian passports became defunct in the eyes of the Chinese officials, because they had already had Chinese citizenship and did not require a family visa for their stay in the country.

\footnotetext{
10 The restrictive domestic legal environment for foreign spouses in China is further aggravated by the absence of the international legal framework to resolve international family disputes over the custody of children, since the PRC (with the exception of Hong Kong and Macao) is not a signatory to the 1980 Hague Convention on the Civil Aspects of International Child Abduction. The PRC is a signatory to the 1990 Convention on the Rights of the Child. Article 8(2) stipulates that "where a child is illegally deprived of some or all of the elements of his or her identity, States Parties shall provide appropriate assistance and protection, with a view to re-establishing speedily his or her identity'. However, because the loss of the second citizenship of the Chinese national child is legally prescribed by Chinese nationality law, the deprivation of an element of the child's foreign identity would not be considered illegal.
} 
Sasha suspected that her husband had registered their daughters in the household registration (hukou) system without letting her know. This had probably occurred, she stated, when they were going through a difficult period in marriage and he worried that she would go back to Russia with the children ${ }^{11}$. She added: 'Chinese men are very worried about it. I know three women whose husbands took children and don't let them see their mothers. The women had to leave China, and their children stayed behind. I know three women like this' (Sasha, 8 August 2016, Changchun). For women of the post-Soviet upbringing with a growing influence of Russian Orthodox culture, their child belongs to them, and they find Chinese men's (and by extension their families' and wider society's) attitudes towards children surprising and infringing on their maternal role. In the words of one research participant, 'where I come from [Ukraine] the new-born baby is her mother's child, while in China the child belongs to the society' (Yaroslava, Shanghai, 21 June 2017). Lena arrived in Beijing almost ten years after Sasha and learnt by chance of possible legal difficulties after becoming a mother in China:

I got pregnant, and we started planning to register our marriage. I went to the Russian embassy in Beijing for advice. I told them that I wanted to marry a Chinese citizen and that I was pregnant. There was a female member of staff who stripped off the rosy glasses I was wearing at the time. She told me about the story of one girl who had given birth to both her children in China and registered them both as Chinese citizens. When things didn't work out and it was time to divorce, the husband took the children to a village in the countryside and the mother did not see her children again. And she advised me: 'Go home, give birth there, and register the child as a Russian citizen. Give birth in Russia and then come back and register your marriage in China. Her words as if woke me up from my dream, and I did as she said (16 August 2016, Vladivostok).

When Lena's marriage did not work out several years later, she recalled her conversation with her former husband: 'He started asking me to give my son to him. You don't need son, he told me. You are 40, you still need to marry. This is his

\footnotetext{
${ }^{11}$ Citizenship rights and welfare provisions in the People's Republic of China are administered through household registration (hukou) system which recognizes its member as a full Chinese citizen with a particular socio-economic and ethnic status. Passports in China are intended for foreign travel rather than domestic use.
} 
Chinese mentality. He was even offering me money so that I leave our son with him'. Lena attributed this prevailing thinking to the long-lasting effects of family planning policies in China and the continuities of traditional marriage values that treat the wife and her children as the property of the husband's family. Despite being the product of the market-oriented socialist government, the family-planning policy revived traditional Confucian attitudes to marriage in unexpected ways (Davis 2014). Having restricted most women to having only one child, it became an unwritten norm for a woman to leave the child with the father's family in case of divorce, because she could marry again and have another child.

With no independent sources of income, temporary dependent residential status in China and no reliable legal support, it is common for women to seek extra assurance of their parental rights through arranging their home country's citizenship for their child. The main advantage of this passport for their children for women living in China is that, if needed, they can quickly leave with the child to their home country.

\section{Engaging citizenship}

I am glad my daughter has a Ukrainian citizenship, just in case. I will never let her come out of the Ukrainian citizenship. It is probably because I am not hundred percent sure (Natasha, Beijing, 6 June 2017).

Although the Chinese state is embracing a seemingly pragmatic, managerial and flexible approach to governing foreigners (Pieke 2012), including the call to hire more foreigners in public office in its global competition for human talent (Yan 2016), the administrative mechanism is lacking transparency, clarity and consistency. The state is actively adapting to the mutations and challenges of maintaining a single citizenship regime against the backdrop of increased migration to and from China. The domain of marriage migration exposes the limitations and tensions in the Chinese governing framework of citizenship and family relations, and the interplay of emotions and geopolitical structures shaping the post-Soviet wives' decisions asserting their parental rights. Their emotional state of uncertainty and 'unspoken fear' (Ho 2009) of separation from their child prompts migrant women to employ their national citizenship as a defense mechanism to secure their parental rights. Their maternal 
subjectivity prompts them to redefine their relationship with and value more their home citizenship.

From the conversations with the women and Russian consulate staff, it emerged that until the mid 2010s, the Chinese authorities eagerly issued Chinese visas in the foreign passports of mixed children, and the children could reside in China on the same one-year and later two-year family visa as their mother. Polina, a Beijing-based research participant, considered herself lucky that she had successfully persuaded her husband to apply for their son to abandon Chinese citizenship in order to become a Russian citizen against the pressure from the local authorities and the Chinese family:

I wanted extra assurance. When I was pregnant, I heard many bad stories about divorces, and awful stories that women were kicked out, that children were taken away or stolen, and that they did not have anywhere to go. Leaving Chinese citizenship wasn't very difficult in the early 2000 s. Now it is more difficult... When my husband took our request to the local immigration office, the people told my husband off as a child: "are you a fool or something, why did you give away your child's citizenship? Our country needs clever people, you have to think about our race!” He was standing there blushing. (Beijing, 31 July 2016).

The local immigration officer's comment is illustrative of the widely held opinion about the role that social reproduction and children play in the idea of continuing and reviving the Chinese race and nation. Indeed, in August 2018 a People's Daily editorial identified having more children as a national concern. ${ }^{12}$ Polina considered her marriage happy and had full trust in her husband who had pursued her for several years in her home town in Russia. Yet, she felt she needed an extra layer of certainty that her son could never be taken away from her. In the absence of the foreign spouses' secure legal status in China, passing on the woman's national citizenship to her child assures her of her parental rights yet compromises the child's Chinese citizenship. Without hukou registration, the child is considered half-citizen, and as such afforded limited rights and responsibilities. Such a child can enjoy certain rights, such as residing in the country without a visa, yet, at the same time, has limited rights, such as access to education. S/he can't go to any public nursery or school, because not

\footnotetext{
12 Zhang, Yiqi 'shen wa shi jia shi ye shi guo shi', Renmin Wang, 6 August 2018 http://politics.people.com.cn/n1/2018/0806/c1001-30210179.html.
} 
every school accepts children without hukou registration. Polina observed that her Chinese parents-in-law had been particularly upset to find out about their grandchild's change of citizenship, because his prospects to pursue a career in civil service or Chinese army would be limited. Several women made the decision concerning their child's citizenship in secret from the Chinese family after learning about the past negative experiences of other women. By securing the link between mother and child's bodies through the mother's national citizenship, the women activate the internal boundary of Chinese citizenship, preventing the child from becoming a full Chinese citizen, yet securing a stronger legal bond between herself and the child. Women actively seek ways to outwit China's single nationality law to assure their parental rights and give more citizenship flexibility to their children. Alyona from Ukraine managed to play the contradictions of national citizenships to her and her child's advantage and arranged two passports for her child. Yet, she admitted that this was risky and one of the citizenships could be revoked at any time.

During the interviews some women and diplomatic staff voiced the opinion that Chinese local officials had been instructed not to issue Chinese visas in foreign passports of children from mixed marriages so that these children had to remain in the territory of China. Having observed this issue for several years, one Russian consulate staff member developed an impression that the Chinese state was trying to 'keep' the children as Chinese nationals. Women expressed similar suspicions at the intuitive level, exacerbated by real uncertainties about their legal status and restrictions to work openly in China. Staking a claim to their home country's citizenship for their children at the expense of Chinese hukou, or finding a way to informally arrange dual citizenship for the children are ways of exercising national citizenship to secure a maternal bond to their Chinese national children in a limited space and constrained rights afforded to foreign wives in China. As permanent foreigners in the Chinese nation, women are pressed to play the limitations of citizenship regulations to secure their maternal bond and pacify their intense fear of separation from their children.

\section{Conclusion}

Historically, citizenship and immigration laws have been drawn by states on behalf of families and communities (Jones and Shen 2008, Harker and Martin 2012: 768). The Chinese marriage experiences of the post-Soviet women and their negotiations of 
parental rights and their children's citizenship show how their foreign status and challenges of adaptation to the Chinese cultural and familial norms heightens their citizenship awareness, albeit in terms of the fear of being separated from their child. In carrying on with this expression of sovereign rule, the Chinese immigration regime in its current form is closer to the pre-revolutionary variants of Chinese citizenship norms than to contemporary versions of citizenship for foreign spouses as practiced by other immigration states, including China's neighbours with similar family norms. ${ }^{13}$ In preventing foreign spouses from a route to full citizenship, the Chinese state continues the Chinese imperial strategy of ethnic acculturation by excluding foreign women yet embracing their mixed-race children into the Chinese cultural sphere. The journey women embarked on to their married life and motherhood in China unleashes not only tremendous emotional efforts of cultural readjustment, but also stimulates an awakening of their national citizenship consciousness in unexpected ways. Caught in a complex web of intimate geopolitics that is informed by the legacies of post-socialist transformations in their home countries and China, and continued inequalities entrenched in Chinese marriage norms, and patriarchal ideologies in both societies and their immigration laws, the post-Soviet women actively negotiate their position in the limited spaces afforded to them. In the absence of legal recognition of their participation in the Chinese society, and scarcely trusting the political system to respect their parental rights, they resort to other resourseful ways to secure their children's citizenships and their maternal rights. The value of passing on a mother's national citizenship to the children takes on a particular significance as a guarantee of the woman's parental rights, thus securing a route of possible return to the home country for both mother and child. Thus, national citizenship becomes an intimate defence mechanism to assert women's maternal rights and subjectivity in case their pursuit of a married life in China comes to an abrupt end.

\section{References}

Atkinson, R. 1998. The Life Story Interview. London: Sage.

\footnotetext{
13 South Korea, Singapore and Taiwan have a large number of foreign spouses constituting the largest segment of their foreign-born population. They have made provisions for a clearly delineated route to national citizenship with economic, social, and political rights for migrant spouses.
} 
Barmé, G. 1995. To screw foreigners is patriotic: China's avant-garde nationalism. The China Journal 34: 209-234.

Bruckerman, C. and S. Feuchtwang. 2016. The Anthropology of China: China as Ethnographic and Theoretical Critique. London: Imperial College Press.

Callahan, W. A. 2004. National insecurities: humiliation, aalvation, and Chinese nationalism. Alternatives 29: 199-218.

Callahan, W. A. 2017. Dreaming as a crticial discourse of national belonging: China dream, American dream and world Dream. Nations and Nationalism 23(2): 248-270.

Chang, S. and H. Wang. 2002. The commodification of international marriages: crossborder marriage business in Taiwan and Vietnam. International Migration 6: 93-116

Chao, A. 2004. The modern state, citizenship, and the intimate life: a case study of Taiwan's glorious citizens and their mainland wives. Taiwanese Sociology 8: 141.

Chen, M. 2015. The "fake marriage" test in Taiwan: gender, sexuality, and border control. Cross-Currents: East Asian History and Culture Review 4(2): 496-518.

Constable, N. 2003 Romance on a Global Stage: Penpals, Virtual Ethnography and 'Mail-Order' Marriages. Berkeley: University of California Press.

Constable, N. 2009. The Commodification of Intimacy: marriage, sex and reproductive labor. Annual Review of Anthropology 38: 49-64.

Davis, D. 2014. Privatisation of marriage in post-socialist China. Modern China 40(6): $551-577$.

Das Gupta, M.; A. Ebenstein; E. J. Sharygin. 2010. China's marriage market and upcoming challenges for elderly men. Policy Research working paper; no. WPS 5351. Washington, DC: World Bank. http://documents.worldbank.org/curated/en/948771468212988136/Chinasmarriage-market-and-upcoming-challenges-for-elderly-men.

Darling, J. 2014. Another letter from the Home office: reading the material politics of asylum. Environment and Planning D 32(3): 484-500.

Faier, L. 2009. Intimate Encounters: Filipina Women and the Remaking of Rural Japan. Berkeley: University of California Press.

Fang, I. 2013. The girls who are keen to get married. In Ordinary Ethics in China, ed. C. Stafford. London: Bloomsbury, pp. 66-79. 
Global Times. 2018. Matchmaking agency owners see China-Russian intermarriages from a Belt\&Road Perspective. Global Times, 26 February, http://www.globaltimes.cn/content/1090770.shtml.

Greenhalgh, S. 2010. Cultivating Global Citizens: Population in the Rise of China. Cambridge, MA: Harvard University Press.

Robinson, K. 2007. Marriage migration, gender transfoprmations, and family values in the 'global ecumene'. Gender, Place and Culture 14(4): 483-497.

Friedman, S. L. 2015. Exceptional States: Chinese Immigrants and Taiwanese Sovereignty. Oakland: University of California Press.

Innes, A. and B. Steele. 2015. Spousal visa law and structural violence: fear, anxiety, and terror of the everyday. Critical Studies on Terrorism 8(3): 401-415.

Jeffreys, E. and P. Wang. 2013. The rise of Chinese-foreign marriage in Mainland China, 1979-2010. China Information 27 (3): 347-69.

Jones, G. and H. Shen. 2008. International marriage in East and Southeast Asia: trends and research emphases. Citizenship Studies 12(1): 9-25.

Jones, G. W. 2012. International marriage in Asia: what do we know, and what do we need to know? Working Paper 174, Singapore, ARI.

Judd, E. 1994. Gender and Power in Rural North China. Stanford: Stanford University Press.

Harker C. and Martin L. 2012. Familial relations: spaces, subjects, and politics. Environment and Planning A 44: 768-75.

Ho, E. L. 2009. Constituting citizenship through the emotions: Singaporean transmigrants in London. Annals of the Association of American Geographers 99(4): 788-804.

Klinke, I. 2016. The Russian cyber-bride as geopolitical fantasy. Royal Dutch Geographical Society 107(2): 189-202.

Liu, G. and B. Ahl. 2018. Recent reform of the Chinese employment-stream migration law regime', China and WTO Review 4: 215-243, https://papers.ssrn.com/sol3/papers.cfm?abstract_id=3222282

Liu, G. 2019. Status quo, challenges, and improvement of Chinese foreign brides immigration policies, paper presented at 'Immigration and the Transformation of Chinese Society' conference, Manchester, 26 April 2019.

Louie, K. 2015. Chinese Masculinities in a Globalizing World. London: Routledge. 
Ní Mhurchú, A. 2016. Thinking with reproduction: maternal time, citizenship, migration and political subjectivity. Subjectivity 9 (1): 17-37.

Greenhalgh, S. 1994. Controlling birth and bodies in village China. American Ethnologist 21(1): 3-30.

Hillier, S. 1988. Women and population control in China: issues of sexuality, power, and control. Feminist Review (29): 101-113.

Humphrey, C. 2002. The Unmaking of Soviet Life: everyday Economies after Socialism. Ithaca: Cornell University Press.

Ong, A. 1999. Flexible Citizenship: The Cultural Logics of Transculturality. Durham: Duke University Press.

Oushakine, S. 2009. The Patriotism of Despaire: Nation, War, and Loss in Russia. Ithaca: Cornell University Press.

Peterson, V. S. 2014a. Antagonizing the 'marriage debate'. Hysteria 4: 33-35.

Peterson, V. S. 2014b. Family matters: how queering the intimate queers the International. Internatioanl Studies Review 16(4): 604-608.

Peterson, V. S. 2017. Guest editorial: towards queering the globally intimate. Political Geography 56: 14-116.

Piper, N. and M. Roces. 2003. eds., Wife or Worker? Asian Women and Migration. Oxford: Rowman \& Littlefield Publishers, Inc.

Santos, G. and S. Harrell. 2015. eds., Transforming Patriarchy: Chinese Families in the Twenty-first Century. Seattle: University of Washington Press.

Säävälä, M. 2010. Forced migrants, active mothers or desired wives: migratiory motivation and selfrepresentation in Kosovo Albanian and Russian women's biographies. Journal of Ethnic and Migration Studies 36(7): 1139-1155.

Schein, L. 1994. The consumption of color and the politics of white skin in post-Mao China', Social Text 41:141-164.

Shen, H. 2012. Understanding China's 'foreign brides' in the framework of transnational migration theory. Journal of Kunming University of Science and Technology 12(5): 6-13.

So, A. Y. 2003. Cross-border families in Hong Kong: the role of social class and politics. Critical Asian Studies 35(4): 515-534.

Stafford, C. 2013. Ordinary ethics in China today. In Ordinary Ethics in China, ed. C. Stafford, 3-25. London: Bloomsbury. 
Teng, E. J. 2013. Eurasian: Mixed Identities in the United States, China, and Hong Kong, 1842-1943. Berkeley: University of California Press.

Mai, N., and King, R. 2009. Love, sexuality and migration. Mobilities 4(3): 295-307.

Jakimow, M. and Barabantseva, E. 2016. Othering in the construction of Chinese citizenship. In Politics of the 'Other' in India and China: Western Concepts in non-Western Contexts, eds. L. Koing and B. Chaudhuri, 167-178. London: Routledge.

Morrison, C-A., Johnston, L. and R. Longhurst. 2012. Critical geographies of love as spatial, relational and political. Progress in Human Geography 37(4): 505-521.

Nyiri, P. 2003. Chinese migration to Eastern Europe. International Migration 41(3): 239-265.

Yan, Y. 2003. Private Life Under Socialism: Love, Intimacy, and Family in Chinese Village, 1949-1999. Stanford: Stanford University Press.

Yan, Y. 2013. The drive for success and the ethics of the striving individual. In Ordinary Ethics in China, ed. C. Stafford, 263- 291. London: Bloomsbury. 